\title{
RELATIVE BINDING AFFINITY OF STEROIDS FOR THE CORTICOSTERONE RECEPTOR SYSTEM IN RAT HIPPOCAMPUS
}

\author{
E. R. De Kloet* $\ddagger$, H. D. Veldhuis*, J. L. Wagenaars $\nmid$ and E. W. Bergink $\dagger$ \\ *Rudolf Magnus Institute for Pharmacology, Medical Faculty, University of Utrecht, Vondellaan 6, 3521 \\ GD Utrecht, and $†$ Scientific Development Group, Organon International B.V., Oss, The Netherlands
}

(Received 23 February 1983)

\begin{abstract}
Summary - In cytosol of the hippocampus corticosterone displays highest affinity for the sites that remain available for binding in the presence of excess RU 26988, which is shown to be a "pure" glucocorticoid. A rather high affinity $(\geqq 25 \%)$ was found for $11 \beta$-hydroxyprogesterone, 21-hydroxyprogesterone, $5 \alpha$-corticosterone, 19-nor-deoxycorticosterone, 11-deoxycorticosterone and cortisol. A moderate affinity $(>5 \%$ and $<25 \%$ was displayed by about 14 steroids among which progesterone, aldosterone, $9 \alpha$-fiuorocortisol and dexamethasone. Corticosterone also shows highest affinity to plasma transcortin and thymus cytosol in the presence of RU 26988. However, the rank-order in affinity by the competing steroids was distinctly different from that observed in the hippocampus; cf. aldosterone and dexamethasone displaced $\left[{ }^{3} \mathrm{H}\right]$ corticosterone from sites unoccupied by RU 26988 in the hippocampus but not from transcortin or sites in thymus cytosol. In thymus cytosol some potent glucocorticoids have higher affinity for the [ $\left.{ }^{3} \mathrm{H}\right] \mathrm{dexamethasone}$ labeled sites than dexamethasone. The binding of ['H]dexamethasone in thymus cytosol is completely abolished in the presence of a 100 -fold excess of RU 26988.

We conclude that our data support the evidence for RU 26988 as a selective ligand for glucocorticoid receptors. RU 26988 leaves binding sites available with highest affinity for corticosterone in hippocampus cytosol that are distinct from transcortin-like sites as found in thymus cytosol or from plasma transcortin.
\end{abstract}

\section{INTRODUCTION}

The rat brain contains receptor sites for adrenocortical steroid hormones [1]. These receptor sites are heterogeneous and can be distinguished in binding specificity, localization and function [2-5]. In vivo administration of tracer amounts of labeled corticosteroids showed pronounced retention of $\left[{ }^{3} \mathrm{H}\right]$ corticosterone $\left(\left[{ }^{3} \mathrm{H}\right] \mathrm{B}\right)$ and $\left[{ }^{3} \mathrm{H}\right]$ aldosterone $\left(\left[{ }^{3} \mathrm{H}\right] \mathrm{ALDO}\right)$ receptor complexes in particular in cell nuclei of the extra-hypothalamic limbic brain regions $[6,7]$. Negligible uptake in cell nuclei of hippocampus was observed for $\left[{ }^{3} \mathrm{H}\right]$ deoxycorticosterone $\left(\left[{ }^{3} \mathrm{H}\right] \mathrm{DOC}\right)$, while the uptake of synthetic glucocorticoids such as $\left[{ }^{3} \mathrm{H}\right]$ dexamethasone $\left(\left[{ }^{3} \mathrm{H}\right] \mathrm{DEX}\right)$ was evenly distributed over the various brain structures $[8,9]$. Prior treatment with ALDO and DOC blocked cell nuclear retention of $\left[{ }^{3} \mathrm{H}\right] \mathrm{B}$, while DEX was a poor competitor [6]. Autoradiographic studies showed the principal localization of $\left[{ }^{3} \mathrm{H}\right] \mathrm{ALDO}$ and $\left[{ }^{3} \mathrm{H}\right] \mathrm{B}$ in cell nuclei of limbic nerve cells, particularly in the hippocampal neurons [10-13], while $\left[{ }^{3} \mathrm{H}\right] \mathrm{DEX}$ labeled neurons in the hypothalamus, and in the non-neural brain tissue, e.g. glial cells and vascular endothelial cells [14-16]. These observations on cellular and regional localization of the labeled steroidreceptor complexes were supported by steroid effects on behavior [17-20,23] and brain biochemistry $[21,22,24-26]$ showing that corticoid

¥To whom correspondence should be addressed. receptor systems in nerve cells and in non-neural tissue functionally should be distinguished [3-6]. Non-neural tissue (glial cells) contains a glucocorticoid receptor system that, in accordance with that occurring in peripheral glucocoricoid target organs, displays the highest responsiveness to synthetic glucocorticoids such as DEX $[3,4,6,26]$. The hippocampal neurons contain a receptor system that is responsive exclusively to $B$, the naturally occurring glucocorticoid of the rat, but that also binds $\operatorname{ALDO}[4,5,6,27,28]$.

In the present study we have investigated the specificity of the remaining corticosterone receptor system after blockade of glucocorticoid receptors with RU 26988 in hippocampus cytosol using a set of 29 reference compounds for competitive binding analysis. A comparison was made between the affinity for these corticosterone receptor sites in hippocampus and thymus cytosol, as well as for transcortin. Also was studied the specificity of the glucocorticoid receptor in thymus using $\left[{ }^{3} H\right] D E X$ as ligand. The data show that highest affinity for the receptor system in the hippocampus is displayed by the naturally occurring glucocorticoid of the rat, corticosterone.

\section{MATERIALS AND METHODS}

\section{Animals and chemicals}

Male Wistar rats (TNO, Zeist, The Netherlands; $160-200 \mathrm{~g}$ body weight) were used. All animals were adrenalectomized 3 days before sacrifice. Bilateral 
adrenalectomy was performed in our laboratory through the dorsal approach, and the rats were supplied with saline in drinking bottles. The rats were caged in groups of 5 at $22^{\circ} \mathrm{C}$ under standard light conditions (14:10 h light-dark period) and allowed food ad libitum.

Unlabeled steroids, except RU 26988, were provided by Organon International B.V. (Oss, The Netherlands). RU 26988 was kindly donated by the Roussel UCLAF Research Centre (Romainville, France). 1,2-[3] $\mathrm{H}]$ Corticosterone (sp. act.: $75 \mathrm{Ci} / \mathrm{mmol}$ ) and 1,2,4-[ $\left.{ }^{3} \mathrm{H}\right]$ dexamethasone (sp. act.: $70 \mathrm{Ci} / \mathrm{mmol}$ ) were obtained from The Radiochemical Center, Amersham, Great Britain.

\section{Binding studies}

For in vitro binding experiments in cytosol, rats were anesthetized with Nembutal ${ }^{\text {B. }}$ and sacrificed by perfusion with saline $(25 \mathrm{ml})$ through the heart. Dissection of hippocampus was performed as described previously [29]. In addition, the thymus was excised.

Cytosol was prepared by homogenizing hippocampal or thymic tissue $(\mathrm{w} / \mathrm{v}=1: 1)$ in $5 \mathrm{mM}$ Tris, containing $1 \mathrm{mM}$ EDTA disodium salt, $1 \mathrm{mM}$ 2-mercaptoethanol and $5 \%$ glycerol, adjusted to $\mathrm{pH}$ 7.4 with hydrochloric acid. The homogenate was centrifuged at $2 \mathrm{C}$ for $1 \mathrm{~h}$ at $105,000 \mathrm{~g}_{\mathrm{av}}$ in an International B-60 ultracentrifuge (IEC, Needham Heights, MA).

Scatchard analyses were performed with the results from incubations in microtitration plates of cytosol $(0.050 \mathrm{ml})$ with $0.05 \mathrm{ml}$ Tris buffer, which contained increasing concentrations of $\left[{ }^{3} \mathrm{H}\right] \mathrm{B},\left[{ }^{3} \mathrm{H}\right] \mathrm{B}+100$-fold excess of unlabeled RU 26988, or with [ $\left.{ }^{3} \mathrm{H}\right] \mathrm{DEX}$. In addition, blood plasma $(0.05 \mathrm{ml})$ diluted 50 -fold with Tris buffer $\mathrm{pH}=7.4$ was incubated with $0.05 \mathrm{ml}$ Tris buffer containing $\left[{ }^{3} \mathrm{H}\right] \mathrm{B}$ or $\left[{ }^{3} \mathrm{H}\right] \mathrm{B}+100$-fold excess RU 26988.

For studies on the relative binding affinity (RBA), a fixed amount ( $3.9 \mathrm{nM})$ of tritiated steroid was used together with various concentrations of unlabeled steroids $(1.95,3.9$ and $7.8 \mathrm{nM})$. A 4-h incubation period of the cytosol or plasma was sufficient to obtain binding equilibrium of the labeled steroids to soluble macromolecules. Subsequent separation of bound and unbound steroid was performed as follows: unbound steroid was removed by incubating, with continuous shaking, for $5 \mathrm{~min}$ the mixture with $0.1 \mathrm{ml}$ Dextran-coated charcoal suspension $(0.25 \%$ charcoal, $0.025 \%$ Dextran-T-70 in Tris buffer). The microtitration plates were then centrifuged at $1500 \mathrm{~g}$ for $15 \mathrm{~min}$. An aliquot of the supernatant $(0.1 \mathrm{ml})$ was added to $9 \mathrm{ml}$ scintillation fluid (Instagel ${ }^{k}$ ) and the radioactivity was counted.

In all experiments the specific activity of the radioactive steroids was used to convert radioactivity to femtomoles of steroid. All data were expressed per $\mathrm{mg}$ cytosol protein. Protein determinations were performed by the biuret method, adapted for the Centrifichem by A. J. M. Degen[30].

\section{RESULTS AND DISCUSSION}

Tahle 1 shows the apparent binding constants of $\left[{ }^{3} \mathrm{H}\right] \mathrm{B}$ in hippocampus cytosol in the absence or presence of a 100-fold excess of RU 26988. Note that the number of binding sites determined in this study is about four times larger than previously reported, which is probably due to the assay: e.g. in this study the Dextran-charcoal method is used instead of the $\mathrm{LH}_{20}$ gelpermeationchromatography. Inclusion of RU 26988 leaves about $75 \%$ of the hinding sites in the hippocampus available for $\left.{ }^{3} \mathrm{H}\right] \mathrm{B}$. RU 26988 does not bind to mineralocorticoid receptors nor to transcortin, but has been used as a selective ligand for glucocorticoid receptors in a number of tissues including the brain [see below, $6,27,28$ ]. In previous work using the $\mathrm{LH}_{20}$ separation technique we found that a 100 -fold excess of RU 26988 displaced $25 \%$ of the $\left[{ }^{3} \mathrm{H}\right]$ binding in hippocampus cytosol (unpublished observation). We also have shown that RU 26988 displaces about $80 \%$ of the binding sites in the hippocampus labeled with [3II]ALDO. These $\left[{ }^{3} \mathrm{H}\right] \mathrm{ALDO}$ sites have been indicated as presumptive mineralocorticoid receptors $[6,27]$. However, these "mineralocorticoid receptors" displayed a higher affinity to B [6]. Therefore, while there is little doubt that RIJ 26988 occupies selectively glucocorticoid receptors, the nature of the binding sites that remain unoccupied in the presence of RU 26988 is at present not clear; these sites could be mineralocorticoid and/or corticosterone preferring receptor types.

Figure 1 shows the competition of various unlabeled ligands $(\mathrm{B}$, progesterone, DEX and triamcinolone acetonide) for the binding of $\left[{ }^{3} \mathrm{H}\right] \mathrm{B}$ to soluble receptor sites in hippocampal cytosol that remain available after occupation of the glucocorticoid sites with RU 26988. Increasing amounts of unlabeled competing steroids were added and the RBA of the various steroids for these sites was calculated from the displacement of [ $\left.{ }^{3} \mathrm{H}\right] \mathrm{B}$ (see legend Table 2).

The RBA-values for binding in hippocampal cytosol of 29 steroids related to the corticoid structure are

Table 1. Comparison of equilibrium dissociation constants $\left(K_{\mathrm{d}}\right)$ and concentration of binding sites for corticosterone $\left(B_{\max }\right)$ in the absence or presence of a 100 -fold excess of RU 26988 in rat thymus and rat hippocampus

\begin{tabular}{|c|c|c|c|c|c|c|}
\hline Ligand & $\begin{array}{c}\text { Thymus } \\
B_{\max }(\mathrm{fmol} / \mathrm{mg} \text { prot. })\end{array}$ & $K_{\mathrm{d}}(\mathrm{nM})$ & $r_{\text {corr. }}$ & $\begin{array}{c}\text { Hippocampus } \\
B_{\max }(\mathrm{fmol} / \mathrm{mg} \text { prot.) }\end{array}$ & $K_{\mathrm{d}}(\mathrm{nM})$ & $r_{\text {corr. }}$ \\
\hline \multirow{2}{*}{$\begin{array}{l}{\left[{ }^{3} \mathrm{H}\right] \text { corticosterone }} \\
{\left[{ }^{3} \mathrm{H}\right] \text { corticosterone }+} \\
100 \text {-fold RU } 26988\end{array}$} & 6650 & 3.1 & 0.93 & 2670 & 2.5 & 0.89 \\
\hline & 4700 & 6.0 & 0.89 & 2050 & 6.5 & 0.88 \\
\hline
\end{tabular}




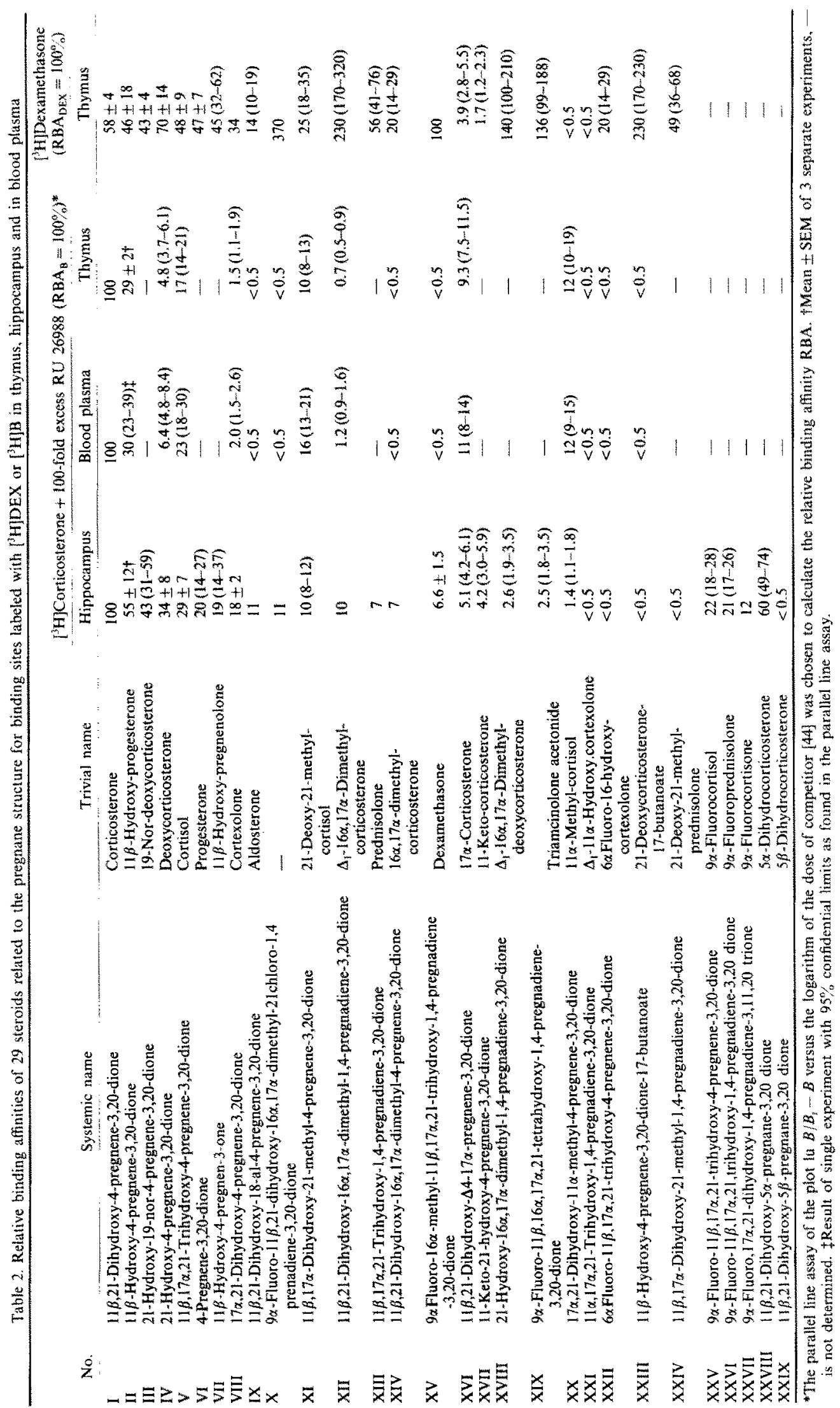




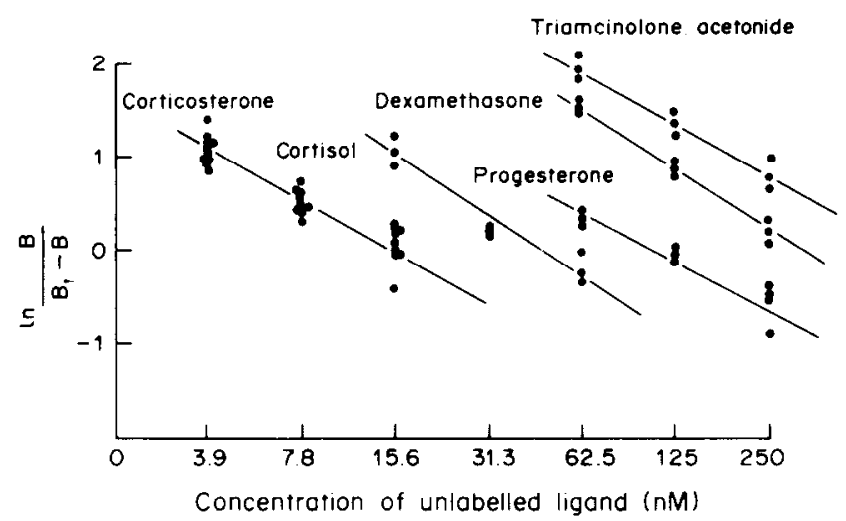

Fig. 1. Competitive binding of $\left[{ }^{3} \mathrm{H}\right] \mathrm{B}$ and various unlabeled ligands $(\mathrm{B}$, cortisol, progesterone, DEX and triamcinolone acetonide) for the receptor system in hippocampal cytosol of the rat. The binding experiment was performed in the presence of a 100-fold excess of unlabeled RU 26988.

given in Table 2 (a similar competition was carried out as with the few examples given in Fig. 1), and compared with the values obtained under identical experimental conditions in thymic cytosol and in diluted blood plasma. The table shows that $B$ has the highest relative affinity for these sites. Consequences of changes in the corticosterone structure for receptor binding in rat hippocampus can be derived from the data.

Some substituents, such as $5 \alpha-\mathrm{H}, 9 \alpha-\mathrm{F}, 17 \alpha-\mathrm{OH}$, 18 -al reduce the affinity. A similar reduction in affinity occurs with the 1-en, 11-deoxy, 19-nor, 21-deoxy, structural modifications. Addition of $5 \beta-\mathrm{H}, 6 \alpha-\mathrm{F}, 11 \alpha-\mathrm{CH}_{3}, 11 \alpha-\mathrm{OH}, 17$-esters or $21-\mathrm{CH}_{3}$ are incompatible with the binding and give steroids with very low RBA values.

In contrast, the fluorosubstituents at position 9 and the introduction of a double bond at sites $C_{12}$ lead to potent glucocorticoids and increase the affinity for the $\left[{ }^{3} \mathrm{H}\right] \mathrm{DEX}$ labeled sites in thymus. Binding constants for [ $\left.{ }^{3} \mathrm{H}\right] \mathrm{DEX}$ labeled sites in thymus are $B_{\max }$ : $3600 \mathrm{fmol} / \mathrm{mg}$ protein; $K_{\mathrm{d}}: 3.8 \mathrm{nM}$. No binding of $\left[{ }^{3} \mathrm{H}\right] \mathrm{DEX}$ occurs in the presence of RU 26988, which supports the evidence for the exclusive glucocorticoid properties of this ligand. Accordingly, these sites are also blocked by RU 26988 in the $\left[{ }^{3} \mathrm{H}\right] \mathrm{B}$ labeled cytosols.

Chemical changes leading to mineralocorticoids do not rcsult in steroids with higher RB $\Lambda$ values than $B$ in the hippocampus. Although the mineralocorticoids display some affinity (cf ALDO: $11 \%$; DOC: $33.5 \%$ ), it is certainly not convincing evidence that the receptor sites labeled with [ $\left.{ }^{3} \mathrm{H}\right] \mathrm{B}$ in this study are solely mineralocorticoid sites. Rather, the presumptive mineralocorticoid sites may well coexist with the specific B receptor sites as pointed out in a previous study [6]. Proof of receptor heterogeneity could be achieved by isolation of the different receptor types by analytical chemical techniques. Progress in purification has been hampered, however, by instability and proteolysis of the brain corticoid receptors [32-34].

$\left[{ }^{3} \mathrm{H}\right] \mathrm{B}$ has the highest affinity to the receptor sites in the hippocampus, but also in blood plasma and in the thymus, when RU 26988 is included. The sites specifically labeled with $\left[{ }^{3} \mathrm{H}\right] \mathrm{B}$ in the hippocampus are not transcortin molecules. Only trace amounts of transcortin have been detected in brain tissue after extensive perfusion [35]. Furthermore, physicochemical properties and other characteristics, such as association of the corticosterone-receptor complex with cell nuclei allows a clear distinction with transcortin [36]. Moreover, although the order of RBA of some compounds is comparable, at many places there is a distinct difference (cf steroids IV, VIII, IX, X, XII, XIV). In contrast, the RBA values for the $B$ binder in the thymus are quite similar with those observed in blood plasma. These molecules could well be transcortin or transcortin-like molecules that remain associated with the tissue, even after extensive perfusion $[37,38,39]$.

In the present study we have attempted to select a series of ligands with a comparable or even more pronounced affinity to the $B$ labeled receptor sites in rat hippocampus. However, B displayed the highest affinity of all steroids tested. This finding is consistent with the unique specificity of $B$ in control of certain behavioral responses [17-20,22], and serotonin synthesis $[21,40-42]$. These indices for neurotransmission and behaviour were not affected by progesterone, DOC, DEX and ALDO. These steroids acted, however, as antagonist when administered prior to $B[22,41]$. Since the present study and a previous one [6] have shown that these steroid hormones have some affinity to $\left[{ }^{3} \mathrm{H}\right] \mathrm{B}$ labeled receptor sites, the antagonism probably occurs via competitive binding at the receptor. The selective action of $B$ in the hippocampus and the highest affinity displayed by this steroid to sites excluded by RU 26988, favour the existence of a population of receptor sites preferring the naturally occurring glucocorticoid of the rat. It is tempting to speculate that this neuronal localized population of receptor sites has its origin early in evolution, since B probably served also as sodium and potassium regulating hormone [43]. The glu- 
cocorticoid receptor specifically blocked by RU 26988 and a separate population of high affinity mineralocorticoid sites (if present) may be later specializations in corticoid receptor phylogeny.

\section{REFERENCES}

1. McEwen B. S., Weiss J. M. and Schwartz L. S.: Uptake of corticosterone by rat brain and its concentration by certain limbic structures. Brain Res. 16 (1969) 227-241.

2. McEwen B. S.: Glucocorticoids and hippocampus: receptors in search for a function. In Current Topics in Neuroendocrinology (Edited by D. Ganten and D. W. Pfaff). Springer, New York (1982) pp.1-22.

3. McEwen B. S. and Micco D. J.: Toward an understanding of the multiplicity of glucocorticoids. In The Brain as an Endocrine Target Organ in Health and Disease (Edited by P. A. van Keep and D. De Wied). MTP Press, Lancaster (1980) pp. 11-28.

4. Bohus B., De Kloet E. R. and Veldhuis H. D.: Adrenal steroids and behavioral adaptation: Relationship to brain corticoid receptors. In Current Topics in Neuroendocrinology (Edited by D. Ganten and D. W. Pfaff). Springer, New York (1982) pp. 107-148.

5. De Kloet E. R. and Veldhuis H. D.: Adrenal corticoid action on the brain. In Handbook of Neurochemistry (Edited by A. Lajtha). Pergamon Press, New York (1984) In press.

6. Veldhuis H. D., Van Koppen C., Van Ittersum M. and De Kloet E. R.: Specificity of the adrenal steroid receptor system in rat hippocampus. Endocrinology 110 (1982) 2044-2051.

7. De Nicola A. F., Tornello S., Weisenberg L., Fridman $O$. and Birmingham $\mathbf{M}$. K.: Uptake and binding of $\left[{ }^{3} \mathrm{H}\right]$ aldosterone by the anterior pituitary and brain regions in adrenalectomized rats. Horm. Metab. Res. 13 (1981) 103-106.

8. McEwen B. S., De Kloet E. R. and Wallach G.: Interactions in vivo and in vitro of corticoids and progesterone with cell nuclei and soluble macromolecules from rat brain regions and pituitary. Brain Res. 105 (1976) 129-136.

9. De Kloet E. R., Wallach G. and McEwen B. S.: Differences in corticosterone and dexamethasone binding to rat brain and pituitary. Endocrinology 96 (1975) 598-609.

10. Gerlach J. L. and McEwen B. S.: Rat brain binds adrenal steroid hormone: radio-autography of hippocampus with corticosterone. Science 175 (1972) 1133-1136.

11. Warembourg M.: Radioautography study of the rat brain after injection of $[1,2]-{ }^{3} \mathrm{H}$-corticosterone. Brain Res, 89 (1975) 61-70.

12. Stumpf W. E. and Sar M.: Steroid hormone target cells in the extra-hypothalamic brain stem and cervical spinal cord: neuroendocrine significance. $J$. steroid Biochem. 11 (1979) 801-807.

13. Ermisch A. and Rühl H. J.: Autoradiographic demonstration of aldosterone concentrating neuropopulations in rat brain. Brain Res. 147 (1978) 154-158.

14. Rhees R. W., Grosser B. I. and Stevens W.: Effect of steroid competition and time on the uptake of $\left[{ }^{3} \mathrm{H}\right]$ corticosterone in the rat brain: an autoradiographic study. Brain Res. 83 (1975) 293-300.

15. Rees H. D., Stumpf W. E. and Sar M.: Autoradiographic studies with ${ }^{3} \mathrm{H}$-dexamethasone in rat brain and pituitary. In Anatomical Neuroendocrinology (Edited by W. E. Stumpf and L. D. Grant). Karger, Basel (1975) pp. 262-269.

16. Warembourg M. Y.: Radioautographic study of rat brain and pituitary after injection of ${ }^{3} \mathrm{H}$-dexamethasone. Cell Tiss. Res. 161 (1975) 183-191.

17. Bohus B., and De Kloet E. R.: Adrenal steroids and extinction behavior: Antagonism by progesterone, deoxycorticosterone, and dexamethasone of a specific effect of corticosterone. Life Sci. 28 (1981) 433-440.

18. Veldhuis H. D., De Kloet E. R., Van Zoest I. and Bohus B.: Adrenalectomy reduces exploratory activity in the rat: a specific role of corticosterone. Horm. Behav. 16 (1982) 191-198.

19. Micco D. J., McEwen B. S. and Shein W.: Modulation of behavioral inhibition in appetitive extinction behavior following manipulation of adrenal steroids in rats: implications for involvement of the hippocampus. $J$. comp. Physiol. Psychol. 93 (1979) 323-329.

20. Micco D. J. Jr and McEwen B. S.: Glucocorticoids, the hippocampus, and behavior: interactive relation between task activation and steroid hormone binding specificity. J. comp. Physiol. Psychol. 94 (1980) 624-633.

21. De Kloet E. R., Kovács G. L., Szabó G., Telegdy G., Bohus B. and Versteeg D. H. G.: Decreased serotonin turnover in the dorsal hippocampus of rat brain shortly after adrenalectomy, selective normalization after corticosterone substitution. Brain Res. 239 (1982) 659663.

22. Veldhuis H. D. and De Kloet E. R.: Antagonistic effects of aldosterone on corticosterone-mediated changes in exploratory behavior of adrenalectomized rats. Horm. Behav. 17 (1983) 225-232.

23. Gray P.: Effect of prestimulation on avoidance responding in rats, and hormonal dependence of the effect. I. comp. Physiol. Psychol. 90 (1976) 1-17.

24. Cousin M. A., Lando D. and Moguilewsky M.: Ornithine decarboxylase induction by glucocorticoids in brain and liver of adrenalectomized rats. $J$. Neurochem. 38 (1982) 1296-1304.

25. De Kloet E. R., Cousin M. A., Veldhuis H. D., Voorhuis Th. D. and Lando D.: Glucocorticoids modulate the response of ornithine decarboxylase to unilateral removal of the dorsal hippocampus. Brain Res. 275 (1983) 91-98

26. Meyer J. S., Leveille P. J., De Vellis J., Gerlach J. L. and McEwen B. S.: Evidence for glucocorticoid target cells in rat optic nerve. Hormone binding and glycerol phosphate dehydrogenase induction. J. Neurochem. 39 (1982) 923-931.

27. Moguilevski M. and Raynaud J. P.: Evidence for a specific mineralocorticoid receptor in rat pituitary and brain. J. steroid Biochem. 12 (1980) 309-314.

28. Coirini H., Marusic E. T., De Nicola A. F., Rainbow T. C. and McEwen B. S.: Identification of mineralocorticoid binding sites in rat brain by competition studies and density gradient centrifugation. Neuroendocrinology 37 (1983) 354-360.

29. Gispen W. H., Schotman P. and De Kloet E. R.: Brain RNA and hypophysectomy; a topographical study. Neuroendocrinology 9 (1972) 285-296.

30. Lane E. A. and Mavrides C.: Automation of the biuret method for samples of low protein concentrations. Analyt. Biochem. 27 (1969) 363-366.

31. McEwen B. S. and Wallach G.: Corticosterone binding to hippocampus: nuclear and cytosol binding in vitro. Brain Res. 57 (1973) 373-386.

32. MacLusky N. J., Turner B. B. and McEwen B. S. Corticosteroid binding in rat brain and pituitary cytosols: resolution of multiple binding components by polyacrylamide gel based isoelectric focussing. Brain Res. 130 (1977) 564-571.

33. Wrange O.: A comparison of the glucocorticoid receptor in cytosol from rat liver and hippocampus. Biochim. biophys. Acta 582 (1979) 346-357.

34. Alexis M. N., Stylianopoulou F., Kilraki E., Sekeris C. E.: The distribution and properties of the glucocorticoid receptor from rat and pituitary. $J$. biol. Chem. 258 (1983) 4710-4714.

35. De Kloet E. R. and McEwen B. S.: Differences between cytosol receptor complexes with corticosterone and 
dexamethasone in hippocampal tissue from rat brain. Biochim. biophys. Acta 421 (1976) 124-132.

36. De Kloet E. R and McEwen B. S.: A putative glucocorticoid receptor and a transcortin-like macromolcculc in pituitary cytosol. Biochim. biophys. Acta 421 (1976) 115-123.

37. Koch B., Lutz B., Briaud B. and Mialhe C.: Heterogeneity of pituitary glucocorticoid binding. Evidence for a transcortin-like compound. Biochim. biophys. Acta 444 (1976) 497-507.

38. De Kloet E. R., Burbach J. P. H. and Mulder G. H.: Localization and role of transcortin-like molecules in the anterior pituitary. Molec. cell Endocr. 7 (1977) 261-273.

39. De Kloet E. R., Voorhuis Th. A. M., Leunissen J. L. M. and Koch B.: Intracellular transcortin-like molecules in the rat pituitary: immunocytochemical localization and function. J. steroid Biochem. (1984) 367-371.
40. Azmitia E. C. Jr and McEwen B. S.: Adrenocortical influence on rat tryptophan hydroxylase activity. Brain Res. 78 (1974) 291-302.

41. Sze P. Y., Neckers L. and Towle A. C.: Glucocorticoids as a regulatory factor for brain tryptophan hydroxylase. J. Neurochem. 26 (1976) 169 173.

42. De Kloet E. R., Kovács G. L. and Versteeg D. H. G.; Aldosterone blocks the response to corticosterone in the raphe-hippocampal serotonin system. Brain Res. 264 (1983) 323-327.

43. Loose D. S. and Feldman D.: Characterization of a unique corticosterone binding protein in Candida albicans. J. biol. Chem. 257 (1982) 4925-4926.

44. Bergink E. W., Hamburger A. D., De Jager E. and Van der Vies J.: Binding of a contraceptive progestagen ORG 2969 and its metabolites to receptor proteins and human sex hormone binding globulin. J. steroid Biochem. 14 (1981) 175-183. 